\title{
Expression Changes of Genes Related to Germination Based on EST Database under Priming Treatment by Gibberellic Acid in Perilla frutescens (Korean Perilla)
}

\author{
Eun Soo Seong ${ }^{1 \dagger}$, Byeong Ju Kang ${ }^{2 \dagger}$, Ji Hye Yoo ${ }^{3}$, Jae Geun Lee ${ }^{4}$, Na Young Kim ${ }^{5}$ and Chang Yeon $\mathrm{Yu}^{2 *}$ \\ ${ }^{1}$ Department of Medicinal Plant, Suwon Women's University, Suwon 16632, Republic of Korea, South Korea \\ ${ }^{2}$ Department of Bio-Resource Sciences, Kangwon National University, Chuncheon 24341, South Korea \\ ${ }^{3}$ Bioherb Research Institute, Kangwon National University, Chuncheon 24341, South Korea \\ ${ }^{4}$ Research Institute of Biotechnology, Hwajin Biocosmetics, Hongcheon 25142, South Korea \\ ${ }^{5}$ Hotel Culinary Arts, Songho University, Hoengseong 25242, South Korea \\ *For correspondence: cyyu@kangwon.ac.kr \\ ${ }^{\dagger}$ Contributed equally to this work and are co-first authors \\ Received 12 January 2021; Accepted 30 April 2021; Published 10 July 2021
}

\begin{abstract}
It is very important to establish an optimal seed priming process in order to increase the vitality of the seeds and promote the metabolism for the germination of the seeds. The optimum concentrations and species of priming agents to improve seed germination of both medicinal plants were also estimated. To improve the germination rate of Perilla frutescens (Korean perilla) seeds, various seed priming agents were used to analyze seed germination rates in the Saeyeopsil, Okdong and 141 collection Korean perilla cultivars. The agents used for seed priming were $\mathrm{CaCl}_{2}, \mathrm{Ca}\left(\mathrm{NO}_{3}\right)_{2}, \mathrm{NaCl}, \mathrm{K}_{3} \mathrm{PO}_{4}$, polyethylene glycol, and gibberellic acid $\left(\mathrm{GA}_{3}\right)$. When $0.1 \mathrm{~m} M \mathrm{GA}_{3}$ was used for seed priming, germination rates of Okdong, and the 141 collection showed a greater than $70 \%$ increase compared to the controls. Nine genes were selected for expression analysis by searching for genes related to seed germination and plant development in the EST (Expressed Sequence Tag) database of the Korean perilla cDNA library. $\mathrm{GA}_{3}$ priming treatment for $1 \mathrm{~d}$ induced higher transcriptional levels of genes related to germination and plant development than controls treated with water only. These genes were identified as protochlorophyllide reductase-like, magnesium-chelatase subunit ChlI, heme-binding protein 2-like, glyceraldehyde 3-phosphate dehydrogenase A, Chlorophyll a-b binding protein 6, B2 protein, 2-Cys peroxiredoxin BAS1, and $21 \mathrm{kDa}$ protein. From these results, we suggest that when priming Korean perilla seeds with $\mathrm{GA}_{3}$, a large number of genes involved in plant development at early stages of seed germination play a role in improving the seed germination rate. Also, these induced genes are ideal candidate biomarkers for seed priming of Korean perilla. Specially, protochlorophyllide reductase-like is thought to be a potential gene for future molecular marker. (C) 2021 Friends Science Publishers
\end{abstract}

Keywords: EST database; $\mathrm{GA}_{3}$; Germination rate; Perilla frutescens; Seed priming

\section{Introduction}

Perilla frutescens is a plant native to regions of Southeast Asia and has various uses such as an ingredient in natural products and food, and as a medicinal pigment (Seong et al. 2009). This plant has long been utilized as a raw material for oil extraction and is commonly known as "Dlggae" in Korea. Recently, consumption of perilla has increased significantly in Korea; more than $60 \%$ of the total unsaturated fatty acids (FAs) in perilla seeds comprises $\alpha$ linolenic acid (Ichikawa 2006), an essential FA required for human growth and development, in addition to its known major role in preventing and treating blood vessel diseases (Shahidi and Miraliakbari 2005). Many flavonoids, sterols, terpenoids and phenolic acids have been extracted from seeds of Korean perilla and studied, with several studies reporting on the importance of flavonoids and phenolic compounds in relation to biological activity (Ozturk et al. 2010; Kim et al. 2019).

Seed priming technology using $\mathrm{Ca}\left(\mathrm{NO}_{3}\right)_{2}, \mathrm{KNO}_{3}$, $\mathrm{MgSO}_{4}, \mathrm{NaNO}_{3}, \mathrm{KCl}, \mathrm{K}_{3} \mathrm{PO}_{4}, \mathrm{NH}_{4} \mathrm{NO}_{3}$ and PEG 6000PEG (polyethylene glycol) involves pretreatment of seeds with different agents with varying concentration, duration, or temperature conditions, with the goal of improving seed production under given environmental conditions (Park et al. 2013). The success of priming is strongly involved in the hydration of the metabolism and process by which the seed absorbs a limited amount of water (Rahimi 2013).

To cite this paper: Seong ES, BJ Kang, JH Yoo, JG Lee, NY Kim, CY Yu (2021). Expression changes of genes related to germination based on EST database under priming treatment by gibberellic acid in Perilla frutescens (Korean perilla). Intl J Agric Biol 26:251-256 
The complex network involved in seed metabolism is dependent on the agent used, duration, and temperature of the priming treatment, as well as vigor, dehydration, and storage conditions of primed seeds (Dezfuli et al. 2008). Seeds priming to enhance seed quality show increase pattern of germination rate which result in high levels of abiotic stress resistance. All these characteristics directly correlate to seed vigour, plant genotype and physiology controlled by multiple genetic and environmental factors (Jisha et al. 2013). Priming method is generally used to treat vegetables seeds such as carrot, celery, lettuce, pepper and tomato (Paparella et al. 2015). However, the establishment of seed priming techniques for medicinal crops is extremely limited. Therefore, it is necessary to improve the germination rate, shorten the number of days it takes to germinate, and establish optimal priming conditions for uniform seedling production in medicinal crops.

The effect of priming has been proven to improve seed germination and seedling growth using numerous chemical factors in various crops such as wheat, beans, sunflower, corn, and brassica (Cho et al. 2011a). For instance, the germination characteristics of corn seeds were improved after gibberellic acid $\left(\mathrm{GA}_{3}\right)$ or hydropriming treatment (Subedi and Ma 2005).

Gibberellic acid $\left(\mathrm{GA}_{3}\right)$ is essential for seed germination and flower development; for example, Arabidopsis exhibiting a deficiency in $\mathrm{GA}_{3}$ content showed defects in seed germination and organ formation (Kim et al. 2014). In addition, loss-of-function studies have identified many genes involved in $\mathrm{GA}_{3}$-induced seed germination (Cao et al. 2006). Genetic markers responding to $\mathrm{GA}_{3}$ may be used to assess the specificity, which AtGA3oxl(GA4) was downregulated by $\mathrm{GA}_{3}$ activity (Silverstone et al. 2001). Gene expression regulated by $\mathrm{GA}_{3}$ during the germination process has also been studied, helping to explain the $\mathrm{GA}_{3}$ response mechanism (Cao et al. 2006).

The purpose of this study was to establish an optimal germination system for Korean perilla through priming treatment, using various agents such as $\mathrm{CaCl}_{2}, \mathrm{Ca}\left(\mathrm{NO}_{3}\right)_{2}$, $\mathrm{NaCl}, \mathrm{K}_{3} \mathrm{PO}_{4}$, polyethylene glycol (PEG), and $\mathrm{GA}_{3}$. In this report, we investigated the germination ratios resulting from the application of all the agents used in the seed priming treatments. Furthermore, this study aimed to reveal the genetic relationship between seed germination and $\mathrm{GA}_{3}$ response, using gene expression data from the Perilla frutescens EST database generated in our previous study (Seong et al. 2015).

\section{Materials and Methods}

\section{Priming treatments for Korean perilla seeds using various agents}

All seeds used in this study were stored at $4{ }^{\circ} \mathrm{C}$ and the priming conditions were tested on three sources of seed: Saeyeopsil, Okdong, and the 141 line. The agents used for priming treatment were $\mathrm{CaCl}_{2}, \mathrm{Ca}\left(\mathrm{NO}_{3}\right)_{2}, \mathrm{NaCl}, \mathrm{K}_{3} \mathrm{PO}_{4}$, PEG 6000 and $\mathrm{GA}_{3}$. The concentrations of $\mathrm{CaCl}_{2}, \mathrm{Ca}\left(\mathrm{NO}_{3}\right)_{2}$, $\mathrm{NaCl}$ and $\mathrm{K}_{3} \mathrm{PO}_{4}$ used were 100,300 and $500 \mathrm{mM}$, respectively, and 0.6 and $-0.9 \mathrm{MPa}$ for PEG $6000 . \mathrm{GA}_{3}$ was used at concentrations of 50,100, 300 and $500 \mu M$. Among priming techniques, osmotic priming and biopriming are the most widely used. Chemicals related to osmotic priming include $\mathrm{CaCl}_{2}, \mathrm{Ca}\left(\mathrm{NO}_{3}\right)_{2}, \mathrm{NaCl}, \mathrm{K}_{3} \mathrm{PO}_{4}$, and PEG 6000, and $\mathrm{GA}_{3}$, a metabolite related to biopriming, was also selected and applied to the experiment. Treatment for concentrations of priming agents and seeds were preceded at $20^{\circ} \mathrm{C}$ for 3 days in a dark condition (Park et al. 2013).

\section{Germination of primed Korean perilla seeds}

Korean perilla seeds were sterilized with $70 \%$ ethanol for 5 min and $1 \%$ hydrogen peroxide for $5 \mathrm{~min}$, and then dried naturally for 1 hour to achieve moisture balance of seeds. Next, $100 \mathrm{~mL}$ of priming solution and $5 \mathrm{~g}$ of sterilized perilla were placed in an Erlenmeyer flask. Priming treatment with $\mathrm{CaCl}_{2}, \mathrm{Ca}\left(\mathrm{NO}_{3}\right)_{2}, \mathrm{NaCl}, \mathrm{K}_{3} \mathrm{PO}_{4}$ and PEG 6000 was carried out for 3 days, at $20^{\circ} \mathrm{C}$ in the dark on a shaking incubator. Priming treatment with $\mathrm{GA}_{3}$ was performed under dark condition at $20^{\circ} \mathrm{C}$ for 1 day.

\section{Gene selection and primer design from the EST databases of Korean perilla}

In our previous study, we analyzed and reported the metabolic classification for genes from the EST database contained in the Korean perilla cDNA library (Seong et al. 2015). As a result of Seong et al. (2015), nine genes related to seed germination were selected for analysis and are shown in Table 1, with numbers and the annotation of the EST database (Seong et al. 2015). To analyze the expression patterns of the 9 selected genes, RT-PCR were performed with 20-mer primers designed using the PICK primer program on the Bioneer homepage (https://www.bioneer.co.kr/index.php/).

\section{RNA extraction from Korean perilla treated with $\mathbf{G A}_{3}$}

The prepared samples were placed in a pre-frozen pestle bowl with liquid nitrogen and ground to a fine powder using a stick. The ground sample was placed in a tube with TRIzol ${ }^{\circledR}$ Reagent (Thermo Fisher Scientific, USA), allowed to stand at room temperature for $5 \mathrm{~min}$, with shaking, for thorough mixing. The samples were separated using a centrifuge at $13000 \mathrm{rpm}$ and the supernatant transferred to a new tube, chloroform was added and left for $10 \mathrm{~min}$, with shaking. The sample was again centrifuged at $13000 \mathrm{rpm}$ and the supernatant transferred to a new tube. The supernatant was slowly mixed with $2-3$ times volume of isopropanol and stored overnight at $-20^{\circ} \mathrm{C}$. The following day, samples were thawed, centrifuged at $13000 \mathrm{rpm}$, and the supernatant discarded. The resulting pellets were washed 
with DEPC-treated $70 \%$ alcohol and dried. The total RNA was dissolved in DEPC-treated sterilized water and quantified on an agarose gel.

\section{RT-PCR analysis}

After cDNA synthesis from the quantified total RNA samples, RT-PCR was performed using primers (forward and reverse) for the Korean perilla actin gene. After confirming the expression level of the actin gene, the RTPCR analysis was performed using primers for genes related to germination (Table 2). PCR conditions were as follows: initial denaturation at $94^{\circ} \mathrm{C}$ for $5 \mathrm{~min} ; 28$ cycles of denaturation at $94^{\circ} \mathrm{C}$ for $1 \mathrm{~min}$, annealing at $55^{\circ} \mathrm{C}$ for $1 \mathrm{~min}$ and $1 \mathrm{~min}$ extension at $72^{\circ} \mathrm{C}$, followed by an additional 10 min extension time at $72^{\circ} \mathrm{C}$. Aliquots of $12 \mu \mathrm{L}$ of the reacted samples were loaded and separated by electrophoresis on a $1 \%$ agarose gel. The reaction was done in triplicate for clarity of results. The band detected on the agarose gel was cloned into a pGEM T-easy vector, followed by sequencing, and homology was confirmed by aligning with sequences of the original genes.

\section{Statistical analysis of germination rates}

After treatment with the priming reagent, a germination test was carried out by in triplicate with 50 seeds for each treatment at $25^{\circ} \mathrm{C}$ for 10 days. To investigate the germination characteristics resulting from priming treatments, the average number of germinating seeds was determined after 15 days and was performed in triplicate. Statistical significance was analyzed using Duncan's Multiple Range Test (DMRT) using the IBM SPSS Statistics software (SPSS v. 23, International Business Machines Corp., Armonk, NY, USA). Statistical significance was determined at the $5 \%$ level.

\section{Results}

\section{Improvement in germination rates by priming of Korean perilla seeds}

In this study, the germination rates of Korean perilla were analyzed after treatment with six priming agents viz. $\mathrm{CaCl}_{2}$, $\mathrm{Ca}\left(\mathrm{NO}_{3}\right)_{2}, \mathrm{NaCl}, \mathrm{K}_{3} \mathrm{PO}_{4}, \mathrm{PEG}$ and $\mathrm{GA}_{3}$. When seeds were primed with $\mathrm{CaCl}_{2}$ at the concentrations of 100,300 and $500 \mathrm{mM}$, the germination rates were $50.00 \pm 1.63 \%$ for Saeyeopsil and $62.00 \pm 1.63 \%$ for line 141 with $100 \mathrm{mM}$, and $68.66 \pm 8.99 \%$ for Okdong with $300 \mathrm{~m} M$. For priming with $\mathrm{Ca}\left(\mathrm{NO}_{3}\right)_{2}$, the germination rate was $56.00 \pm 2.82 \%$ at $100 \mathrm{~m} M$ for Saeyeopsil and $72.66 \pm 8.37$ and $61.33 \pm 6.79 \%$ at $300 \mathrm{~m} M$ for Okdong and line 141, respectively. The germination rate for all Korean perilla seeds primed with $100 \mathrm{~m} M \mathrm{NaCl}$ ranged from $44.00 \pm 3.26$ to $53.33 \pm 8.21 \%$. However, $\mathrm{NaCl}$ treatment resulted in a lower germination rate compared to the control without priming treatment. The germination rate for the priming treatment with $-0.96 \mathrm{MPa}$ PEG was $58.00 \pm 4.32 \%$ for Saeyeopsil and $64.00 \pm 4.32 \%$ for Okdong, respectively. For the 141 collection, was higher value as $55.33 \pm 2.49 \%$ in that of $-0.6 \mathrm{MPa}$ PEG. Priming with $0.1 \mathrm{~m} M \mathrm{GA}_{3}$ showed the best values among the priming treatment agents for all the Korean perilla seeds, presenting values ranging from $62.66 \pm 1.88$ to $70.66 \pm$ $4.10 \%$. However, no germination was observed with treatment at any concentration of $\mathrm{K}_{3} \mathrm{PO}_{4}$. Among various priming agents, 'Saeyeopsil' and 'Okdong' showed a high germination rate of $60 \sim 70 \%$ or more under $\mathrm{GA}_{3}$ treatment, and '141 collection' showed a high germination rate of $70 \%$ or more under treatment with $100 \mathrm{mM} \mathrm{CaCl}_{2}$ or $0.1 \mathrm{~m} M$ $\mathrm{GA}_{3}$ (Table 3).

\section{Gene expression by $\mathbf{G A}_{3}$-priming treatment in Korean perilla}

As $\mathrm{GA}_{3}$ proved to be the most effective at increasing germination rates in Korean perilla among all the priming agents used, it was selected as the priming agent for the analysis of the expression patterns of nine genes related to plant development. Gene expression patterns were compared between Korean perilla seeds treated or untreated with $0.1 \mathrm{mM} \mathrm{GA}_{3}$ for $1-5 \mathrm{~d}$. We found no significant difference in the transcriptional levels of genes between $\mathrm{GA}_{3}$ treated and untreated controls in Saeyeopsil. However, gene expression levels were higher in Okdong seeds treated for $1 \mathrm{~d}$ with $\mathrm{GA}_{3}$ than in the water-only controls. The genes showing the greatest induction after $\mathrm{GA}_{3}$ treatment for $1 \mathrm{~d}$, were: protochlorophyllide reductase-like, magnesium chelatase subunit ChlI, heme-binding protein 2-like, glyceraldehyde 3-phosphate dehydrogenase A (GAPDH), Chlorophyll a-b binding protein 6 (LHCP), B2 protein, 2 Cys peroxiredoxin BAS1, and $21 \mathrm{kDa}$ protein (Fig. 1).

Higher transcriptional levels were also observed for 141 collection seeds with $\mathrm{GA}_{3}$ treatment for $1 \mathrm{~d}$ compared to controls. The highest expression levels were recorded for protochlorophyllide reductase-like, magnesium chelatase subunit ChlI, heme-binding protein 2-like, GAPDH, 2-Cys peroxiredoxin BAS1 and $21 \mathrm{kDa}$ protein. Gene expression in Korean perilla seeds treated with $\mathrm{GA}_{3}$ for $5 \mathrm{~d}$ showed a similar expression pattern compared to water treatment alone (Fig. 1). These results show that various genes are involved in seed germination metabolism during the early stages in Korean perilla seeds primed with $\mathrm{GA}_{3}$.

\section{Discussion}

In general, priming agents should be free of toxicity and kept under constant water conditions for effective plant growth. Priming treatment agents inhibit cellular osmotic regulation, and high concentrations of ions can inhibit germination by destroying enzymes and membrane (Seo et al. 2009). The ion concentrations of the priming solution can affect germination and seedling appearance, as the 
Seong et al. / Intl J Agric Biol, Vol 26, No 2, 2021

Table 1: Genes related to germination analyzed from the EST data of Korean perilla cDNA library

\begin{tabular}{ll}
\hline EST NO. & Annotations by blast results of EST \\
\hline Perilla-1-1a_pTriplEx2-seq_E22 & PREDICTED: 1-aminocyclopropane-1-carboxylate oxidase [Sesamum indicum] \\
Perilla-1-4a_pTriplEx2-seq_J14 & PREDICTED: 21 kDa protein [Sesamum indicum] \\
Perilla-1-2a_pTriplEx2-seq_M18 & PREDICTED: 2-Cys peroxiredoxin BAS1, chloroplastic-like [Sesamum indicum] \\
Perilla-2-1a_pTriplEx2-seq_I15 & PREDICTED: B2 protein [Sesamum indicum] \\
Perilla-1-1a_pTriplEx2-seq_C22 & PREDICTED: chlorophyll a-b binding protein 6, chloroplastic [Sesamum indicum] \\
Perilla-1-1a_pTriplEx2-seq_A24 & PREDICTED: glyceraldehyde-3-phosphate dehydrogenase A, chloroplastic [Sesamum indicum] \\
Perilla-3-2a_pTriplEx2-seq_G10 & PREDICTED: heme-binding protein 2-like [Sesamum indicum] \\
Perilla-1-1a_pTriplEx2-seq_K12 & PREDICTED: magnesium-chelatase subunit ChII, chloroplastic-like [Sesamum indicum] \\
Perilla-2-2a_pTriplEx2-seq_C12 & PREDICTED: protochlorophyllide reductase-like [Sesamum indicum] \\
\hline
\end{tabular}

Table 2: The primers designed to gene expression of EST selected from Korean perilla cDNA library

\begin{tabular}{lll}
\hline Actin gene and EST No. & Forward & Reverse \\
\hline Pfactin & ACAGAGGCACCTCTCAACCC & ATCACGACCAGCAAGATCCA \\
Perilla-1-1a_pTriplEx2-seq_E22 & GCGAAAACTGGGGTTTCTTC & AGGAAGAAGGTGCTCTCCCA \\
Perilla-1-4a_pTriplEx2-seq_J14 & TGGAGGAGCTGTCTGACTCG & CGCCACATTCACAATCTTCC \\
Perilla-2-2a_pTriplEx2-seq_M18 & CTAGTGACCGAGTGCCGAGA & GCTTGCAAGTGCTTCGTTTC \\
Perilla-2-1a_pTriplEx2-seq_I15 & GTGCATGGCAACCTACAAGG & GATGCACGTAAGCACCCATC \\
Perilla-1-1a_pTriplEx2-seq_C22 & CCGTCCTCTCTTCCTCCAAG & GTGGGTCGAATCCGAAACT \\
Perilla-1-1a_pTriplEx2-seq_A24 & TTGTGATCGAGGGAACTGGA & AGGAAGCGTTGCTGATGATG \\
Perilla-3-2a_pTriplEx2-seq_G10 & TGATTTGGAGGATATCGGCA & CCTCTCTTTGTGAAAGGGGC \\
Perilla-1-1a_pTriplEx2-seq_K12 & GAGCCAGAGGCCAGTTTACC & TCTCCCTCACTTCAGGACCC \\
Perilla-2-2a_pTriplEx2-seq_C12 & CCCCTCTAACAAGGGAGCAG & GTTCGGGTACACTGACACGC \\
\hline
\end{tabular}

agents penetrate into the seeds and may have toxic effects. Additionally, increases in ion accumulation of a priming solution can reduce the priming effect by interfering with metabolism (Seo et al. 2009).

In a previous report, the germination rate of Hippophae rhamnoides seeds was shown to $52.6 \%$ of 300 $\mathrm{m} M$ and $50.9 \%$ of $400 \mathrm{~m} M$ under $\mathrm{CaCl}_{2}$ priming treatment, respectively (Choi 2012). On the contrary, in a priming study of Sorbus alnifolia seed, $\mathrm{CaCl}_{2}$ treatment resulted in a reduced germination rate compared to the control (Park et al. 2013). $\mathrm{Ca}\left(\mathrm{NO}_{3}\right)_{2}$ priming treatments for Saeyeopsil and Okdong produced higher germination rates than with $\mathrm{CaCl}_{2}$. $\mathrm{Ca}\left(\mathrm{NO}_{3}\right)_{2}$ priming treatment was effective in tomato, but application resulted in a decrease when compared to the control in sesame seeds (Cho et al. 2011b). This indicates that the effect of priming treatment is crop-dependent. In this study, the germination rates with the $\mathrm{NaCl}$ priming treatment were lower compared to the non-treated controls, while $\mathrm{K}_{3} \mathrm{PO}_{4}$-treatment completely inhibited germination. Inorganic salts such as $\mathrm{NaCl}$ and $\mathrm{K}_{3} \mathrm{PO}_{4}$ are often used when salt priming is applied. Nitrogen-containing salts are more effective at improving germination rates than salts containing phosphoric acid (Bose et al. 2018). However, in this report, germination rates of Korean perilla seeds did not show any improvement with $\mathrm{NaCl}$ priming treatment.

PEG is known to play a role in regulating osmotic equilibrium (Ismail et al. 2005). The germination rates of Korean perilla seeds under PEG priming treatment increased compared to the controls, as was previously reported for germination rates and germinative power of Alnus sibirica (Park et al. 2013). In the case of Zanthoxylum piperitum seeds, $\mathrm{GA}_{3}$ has been reported to increase the germination rate with increasing immersion time and concentration (Lim et al. 2015). The germination rate was significantly improved with $\mathrm{GA}_{3}$ levels of $25 \mathrm{ppm}$, and the germination rate tended to increase with increasing $\mathrm{GA}_{3}$ concentrations in Lithospermum erythrorhizon seed (Kim et al. 2014). Among all the priming agents tested, the results indicate that $\mathrm{GA}_{3}$ had the greatest effect, showing an increase of over $70 \%$ in the germination rates of Okdong and the 141 collection cultivars of Korean perilla.

In the past, many studies on seed priming with $\mathrm{GA}_{3}$ and related genes in various plants such as vegetables or Arabidopsis have been reported, but these results are very limited in medicinal plants (Ogawa et al. 2003). Therefore, in our results, optimal germination conditions of Korean perilla were established during $\mathrm{GA}_{3}$ priming, so we studied to analyze the correlation with genetic changes at the cellular level. DNA repair and antioxidant mechanisms are involved in minimization of growth inhibition for seeds during seedling development. The effects of the priming agent on DNA repair mechanisms are essential to optimize priming methods (Balestrazzi et al. 2015). Therefore, the induced genes according to the establishment of priming optimization during seed germination of Korean perilla were identified. It is expected that these genes can be used as biomarkers to create a cultivation environment that increase the germination rate of Korean perilla by investigating genes induced during seed germination using $\mathrm{GA}_{3}$.

In peas, protochlorophyllide reductase has been shown to play a post-transcriptional regulatory role in protein elongation and conversion. Protein expression patterns differ between monocots and dicots, but protochlorophyllide reductase is present in higher plants (Cahoon and Timko 2000). Magnesium-chelatase subunit ChII is known to be active in plant-cell interactions, chelating magnesium on protoporphyrin IX and mediating plastid-to nucleus retrograde signaling (Papenbrock et al. 2000; Nott et al. 
Expression of Genes Related to Germination of Perilla frutescens / Intl J Agric Biol, Vol 26, No 2, 2021

Table 3: Germination rate of three different cultivars depending on priming treatments in Perilla frutescens

\begin{tabular}{|c|c|c|c|c|}
\hline \multirow[t]{2}{*}{ Seed Treatment } & \multicolumn{4}{|c|}{ Perilla frutescens } \\
\hline & & Saeyeopsil & Okdong & 141 collection \\
\hline Priming Agents & Concentrations & Germination rate (\%) & & \\
\hline Control & & $46.67 \pm 12.85^{\text {bdef }}$ & $58.00 \pm 5.29^{\mathrm{de}}$ & $54.67 \pm 1.15^{\text {cdefg }}$ \\
\hline \multirow[t]{3}{*}{$\mathrm{CaCl}_{2}$} & $100 \mathrm{~m} M$ & $50.00 \pm 2.00^{\text {abcef }}$ & $62.00 \pm 3.46^{\mathrm{cd}}$ & $75.33 \pm 3.06^{\mathrm{a}}$ \\
\hline & $300 \mathrm{~m} M$ & $32.67 \pm 5.77^{\mathrm{g}}$ & $68.66 \pm 11.02^{\mathrm{abc}}$ & $49.33 \pm 3.06^{\mathrm{fg}}$ \\
\hline & $500 \mathrm{~m} M$ & $42.00 \pm 2.00^{\mathrm{efg}}$ & $56.67 \pm 4.62^{\mathrm{de}}$ & $45.33 \pm 6.43^{\mathrm{g}}$ \\
\hline \multirow{3}{*}{$\mathrm{Ca}\left(\mathrm{Na}_{3}\right)_{2}$} & $100 \mathrm{~m} M$ & $56.00 \pm 3.46^{\mathrm{bccd}}$ & $69.33 \pm 8.33^{\mathrm{abc}}$ & $59.33 \pm 7.02^{\text {cdef }}$ \\
\hline & $300 \mathrm{~m} M$ & $54.00 \pm 6.93^{\text {abce }}$ & $72.67 \pm 10.26^{\mathrm{ab}}$ & $61.33 \pm 8.32^{\text {bde }}$ \\
\hline & $500 \mathrm{~m} M$ & $43.33 \pm 12.22^{\operatorname{defg}}$ & $60.67 \pm 3.06^{\mathrm{cd}}$ & $48.67 \pm 2.31^{\mathrm{g}}$ \\
\hline \multirow[t]{3}{*}{$\mathrm{NaCl}$} & $100 \mathrm{~m} M$ & $44.00 \pm 4.00^{\text {cdefg }}$ & $55.33 \pm 5.03^{\mathrm{de}}$ & $53.33 \pm 10.07^{\mathrm{defg}}$ \\
\hline & $300 \mathrm{~m} M$ & $40.00 \pm 4.00^{\mathrm{fg}}$ & $50.00 \pm 6.00^{\mathrm{e}}$ & $48.67 \pm 7.02^{\mathrm{g}}$ \\
\hline & $500 \mathrm{mM}$ & $34.00 \pm 3.46^{\mathrm{g}}$ & $50.00 \pm 2.00^{\mathrm{e}}$ & $33.33 \pm 6.10^{\mathrm{h}}$ \\
\hline \multirow{3}{*}{$\mathrm{K}_{3} \mathrm{PO}_{4}$} & $100 \mathrm{~m} M$ & ND & ND & ND \\
\hline & $300 \mathrm{~m} M$ & ND & ND & ND \\
\hline & $500 \mathrm{~m} M$ & ND & ND & ND \\
\hline \multirow[t]{2}{*}{ PEG } & $-0.6 \mathrm{Mpa}$ & $48.67 \pm 16.65^{\text {bcdef }}$ & $62.00 \pm 10.39^{\mathrm{cd}}$ & $55.33 \pm 3.06^{\text {defg }}$ \\
\hline & $-0.9 \mathrm{Mpa}$ & $58.00 \pm 5.29^{\mathrm{ab}}$ & $64.00 \pm 5.29^{\mathrm{bcd}}$ & $51.33 \pm 4.16^{\mathrm{efg}}$ \\
\hline \multirow[t]{4}{*}{$\mathrm{GA}_{3}$} & $0.05 \mathrm{~m} M$ & $62.00 \pm 2.00^{\mathrm{a}}$ & $74.67 \pm 2.31^{\mathrm{a}}$ & $59.33 \pm 9.02^{\text {cdef }}$ \\
\hline & $0.1 \mathrm{~m} M$ & $62.67 \pm 2.31^{\mathrm{a}}$ & $78.67 \pm 4.16^{\mathrm{a}}$ & $70.67 \pm 5.03^{\mathrm{ab}}$ \\
\hline & $0.3 \mathrm{~m} M$ & $54.00 \pm 7.21^{\text {abce }}$ & $74.00 \pm 2.00^{\mathrm{ab}}$ & $63.33 \pm 5.03^{\text {bcd }}$ \\
\hline & $0.5 \mathrm{~m} M$ & $56.66 \pm 5.03^{\mathrm{abc}}$ & $75.33 \pm 1.15^{\mathrm{a}}$ & $64.66 \pm 4.16^{\mathrm{bc}}$ \\
\hline
\end{tabular}

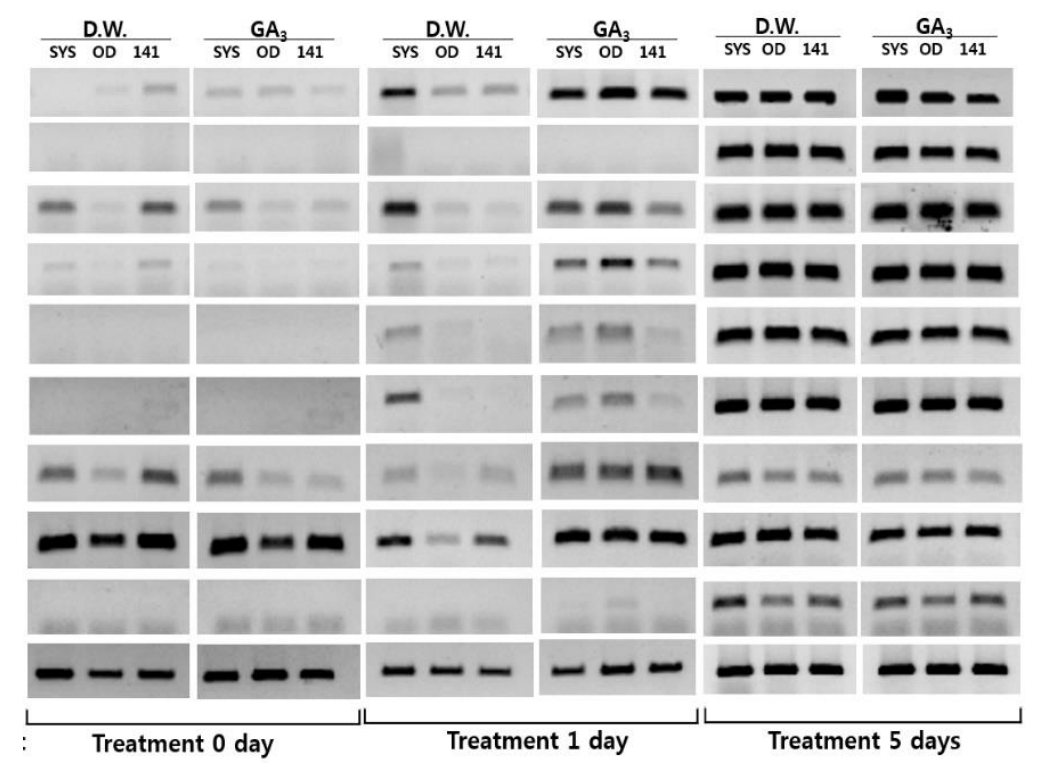

Fig. 1: Expression patterns of genes related to germination from EST analysis data of Korean perilla after seed priming with water and GA 3

2006). HBP is induced by oxidative stress and is involved in various functions of the protein (Lee et al. 2012). GAPDH catalyzes the conversion of glyceraldehyde-3-phosphate to 1,3-bisphosphoglycerate and has two isoforms, GAPCp1 and GAPCp2, both of which are important for the plastidial glycolytic pathway in plant primary metabolism (MunozBertomeu et al. 2009). The LHCP gene shows an expression pattern specific to chloroplast-containing tissue, and mRNA expression can be determined by its associated factors (Wang and Grimm 2021). The 2-Cys peroxiredoxin BAS1 gene has antioxidant properties that regulate cellular redox states and is associated with the soluble chloroplast fraction function of mesophyll protoplasts in higher plants (Cerveau et al. 2016).

\section{Conclusion}

In this study, genes from the Korean perilla selected from the EST database that were induced by $\mathrm{GA}_{3}$ treatment are related to oxidative stress, plastidial metabolism, tissue specificity, redox reactions, and chloroplast function in plant cells. It was found that the method to increase the germination rate of Korean perilla is the optimal concentration treatment of $\mathrm{GA}_{3}$. Under this optimal condition, these marker genes such as protochlorophyllide reductase-like, magnesium-chelatase subunit ChlI, heme-binding protein 2-like, glyceraldehyde 3phosphate dehydrogenase A, and Chlorophyll Since ab binding protein $6, \mathrm{~B} 2$ protein, 2-Cys peroxiredoxin BAS1, and $21 \mathrm{kDa}$ protein genes are induced and this pattern is 
thought to be involved in $\mathrm{GA}_{3}$ priming. We suggest that these genes induce substances related to the initial stages of germination metabolism of Korean perilla seeds under $\mathrm{GA}_{3}$ priming, thus improving the germination rate. In the future, we propose studying the functional relationship between these genes and the germination of Korean perilla seeds.

\section{Acknowledgements}

This study was supported by the Bioherb Research Institute, Kangwon National University, Republic of Korea.

\section{Author Contributions}

ES Seong and BJ Kang performed experiment design and writing of manuscript. CYY supervised the experi ment. JH Yoo, JG Lee and NY Kim performed editing of manuscript.

\section{Conflicts of Interest}

The authors declare that they have no confict of interest.

\section{Data Availability}

Data presented in this study are available with the authors.

\section{Ethics Approval}

There are no researches conducted on animals or human.

\section{References}

Balestrazzi A, M Dona, A Macovei, ME Sabatini, A Pagano, D Carbonera (2015). DNA repair and telomere maintenance during seed imbibition: Correlation of transcriptional patterns. Telomere Telomerase 2; Article e495

Bose B, M Kumar, RK Singhal, S Mondal (2018). Impact of seed priming on the modulation of physico-chemical and molecular processes during germination, growth, and development of crops. In: Advances in Seed Priming, pp:23-40. Rakshit A, H Singh (Eds). Springer, Singapore

Cahoon AB, MP Timko (2000). Yellow-in-the-dark mutants of Chlamydomonas lack the CHLL Subunit of light-independent protochlorophyllide reductase. Plant Cell 12:559-568

Cao D, H Cheng, W Wu, HM Soo, J Peng (2006). Gibberellin mobilizes distinct DELLA-dependent transcriptomes to regulate seed germination and floral development in Arabidopsis. Plant Physiol 142:509-525

Cerveau D, A Kraut, HU Stotz, MJ Mueller, Y Coute, P Rey (2016). Characterization of the Arabidopsis thaliana 2-Cys peroxiredoxin interactome. Plant Sci 252:30-41

Cho SK, KB Shim, YJ Oh, SB Lee (2011a). Effect of priming conditions on enhancing germination of sesame (Sesamum indicum L.) Seed. J Kor Soc Intl Agric 23:395-401

Cho SK, KB Shim, YJ Oh, SB Lee, JJ Lee, KM Cho, TI Park, OK Han, KJ Kim (2011b). Effect of priming conditions on enhancing germination of sesame (Sesamum indicum L.) seed. Kor J Intl Agric 23:395-401

Choi $\mathrm{CH}$ (2012). effect of temperature and various pre-treatments on germination of Hippophae rhamnoides seeds. Kor J Plant Res 25:132-141

Dezfuli PM, F Sharif-zadeh, M Janmohammadi (2008). Influence of priming techniques on seed germination behavior of maize inbred lines (Zea mays L.). ARPN J Agric Biol Sci 3:22-25

Ichikawa K (2006). Nutritional properties and utilization of perilla seed oil (in Japanese). J Oleo Sci 6:257-264
Ismail AI, MM El-Araby, AZA Hegazi, SMA Moustafa (2005). Optimization of priming benefits in tomato (Lycopersicon esculentum M.) and changes in some osmolytes the hydration phase. Asia J Plant Sci 4:691-701

Jisha KC, K Vijayakumari, JT Puthur (2013). Seed priming for abiotic stress tolerance: An overview. Acta Physiol Plantarum 35:1381-1396

Kim DH, BJ Ahn, HJ An, YS Ahn, CG Park, SW Cha, BH Song (2014). Studies on seed germination characteristics and patterns of protein expression of Lithospermum erythrorhizon by plant growth regulators and seed primings. Kor Med Crop Sci 22:435-441

Kim HW, DS Kim, NY Sung, IJ Han, BS Lee, SY Park, J Eom, JY Suh, J Park, A Yu, JS Kim (2019). Development of functional cosmetic material using a combination of Hippophae rhamnoides fruit, Rubus fruticosus leaf and Perillae folium leaf extracts. Asian J Beauty Cosmetol 17:477-488

Lee HJ, N Mochizuki, T Masuda, TJ Buckhout (2012). Disrupting the bimolecular binding of the haem-binding protein 5 (AtHBP5) to haem oxygenase 1 (HY1) leads to oxidative stress in Arabidopsis. $J$ Exp Bot 63:695-709

Lim HI, GN Kim, KH Jang, WG Park (2015). Effect of wet cold and gibberellin treatments on germination of dwarf stone pine seeds. Kor $J$ Plant Res 28:253-258

Munoz-Bertomeu J, B Cadcales-Minana, JM Mulet, E Baroja-Fernández, J Pozueta-Romero, JM Kuhn, J Segura, R Ros (2009). Plastidial glyceraldehyde-3-phosphate dehydrogenase deficiency leads to altered root development and affects the sugar and amino acid balance in Arabidopsis. Plant Physiol 151:541-558

Nott A, HS Jung, S Koussevitzky, J Chory (2006). Plastid-to-nucleus retrograde signaling. Anпи Rev Plant Biol 57:739-759

Ogawa M, A Hanada, Y Yamauchi, A Kuwahara, Y Kamiya, S Yamaguchi (2003). Gibberellin biosynthesis and response during Arabidopsis seed germination. Plant Cell 15:1591-1604

Ozturk M, ME Duru, B Ince, M Harmandar, G Topcu (2010). A new rapid spectrophotometric method to determine the rosmarinic acid level in plant extracts. Food Chem 123:1352-1356

Paparella S, SS Arau, G Rossi, M Wijayasinghe, D Carbonera, A Balestrazzi (2015). Seed priming: State of the art and new perspectives. Plant Cell Rep 34:1281-1293

Papenbrock J, HP Peter-Mock, R Tanaka, E Kruse, B Grimm (2000). Role of magnesium chelatase activity in the early steps of the tetrapyrrole biosynthetic pathway. Plant Physiol 122:1161-1169

Park HI, HS Shim, LN Choi, SH Han, JG Lee, CY Yu, JD Lim (2013). Effect of priming and seed pellet technique for improved germination and growth in Fraxinus rhynchophylla and Alnus sibirica. Kor J Med Crop Sci 21:7-19

Rahimi A (2013). Seed priming improves the germination performance of cumin (Cuminum syminum L.) under temperature and water stress. Indus Crops Prod 42:454-460

Seo BS, CH Choi, WJ Park (2009). Effect of priming treatments on seed germination and seedling growth of Sorbus alnifolia. Kor J Plant Res 22:5-12

Seong ES, JH Yoo, JH Choi, CH Kim, MR Jeon, BJ Kang, JG Lee, SK Choi, BK Ghimire, CY Yu (2015). Expressed sequence tags analysis and design of simple sequence repeats markers from a full-length cDNA Library in Perilla frutescens (L.). Intl J Genomics 2015; Article 679548

Seong ES, EW Seo, HS Kim, K Heo, JK Lee, IM Chung, BK Ghimire, MJ Kim, JD Lim, CY Yu (2009). Molecular characterization of the Perilla frutescens limonene gene (PFLS) by agroinfiltration into Nicotiana benthamiana. Kor J Med Crop Sci 17:33-38

Shahidi F, H Miraliakbari (2005). Omega-3 fatty acids in health and disease. Part 2. health effects of omega-3 fatty acids in autoimmune diseases, mental health, and gene expression. J Med Food 8:133-148

Silverstone AL, HS Jung, A Dill, H Kawaide, Y Kamiya, TP Sun (2001). Repressing a repressor: Gibberellin-induced rapid reduction of the RGA protein in Arabidopsis. Plant Cell 13:1555-1565

Subedi KD, BL Ma (2005). Seed priming does not improve corn Yield in a humid temperate environment. Agron J 97:211-218

Wang P, B Grimm (2021). Connecting chlorophyll metabolism with accumulation of the photosynthetic apparatus. Trends Plant Sci $26: 484-495$ 